\title{
THE EFFECT OF GOVERNMENT POLICY \\ ON USING FEWER PLASTIC BAGS TOWARDS \\ SOCIETY'S AWARENESS OF GOING GREEN
}

\author{
Kuswardhani, Dra., M.Ed. \\ Sekolah Tinggi Pariwisata Bandung \\ (kuswardhaninaniek@gmail.com)
}

\author{
Zulhelfa, Dra., M.Hum. \\ Sekolah Tinggi Pariwisata Bandung \\ (zulhelfa@gmail.com)
}

\begin{abstract}
The environment and ecosystem life of human being couldn't be apart from natural environment and social environment. Darsono (1995) stated that environment means a place where human beings live with their activities and everything around the society could affect the development of human being life directly or indirectly. It is proved that Indonesia was accused as the second country that has produced the biggest plastic trash in the world, as stated by Jenna Jamback in Rahyang Nusantara (2016).

Due to keep green environment, Indonesian Government stated that using fewer plastic bag to press the quantity of plastic trash in order not to make harm environment. Therefore, The government Bandung City stated local regulation (Perda No.17 tahun 2012) that decreasing the use of plastic bags which their basic materials are not disentangled easily could damage the quality of environment. It is also supported by Amendment from The Ministry of Environment and Forestry (Surat Edaran No, S.1230/PSLB3-PS/2016)

The purpose of this research is to find out how care the society of keeping the environment green. This research uses qualitative descriptive methodology by interviewing supervisor of super markets in Bandung.
\end{abstract}

Keywords: green environment, regulation, society, plastic bag, human being life.

\section{INTRODUCTION}

Plastic bags in Indonesia are commonly used as shopping bags for packaging food and other items. However, plastic bags are used as multi purposes, not only as shopping bags but they are also very useful for house wives especially in their daily activities. The useful of plastic bags for mothers and house wives make them really rely on them. If the plastic bags are still clean, they will save them and use them again for packaging any items or finally they will use them as trash bags. If the plastic bags are not in good condition or dirty, they will throw them away directly. As every house produces rubbish everyday, so plastic bags are also used as trash bags and throw them away to the temporary landfills. It seems, the society doesn't care to what happens in the landfills with the plastic bags.

Considering to Indonesian population is very high that is related to the characteristic of society who like shopping very much, causes of using very high plastic bags in Indonesia. As stated by Rahyang Nusantara (2016:01) that
Indonesia has a very serious problem with rubbish which is produced everyday, only in our capital city reaches 6.000 ton and the piles of litter is $30.000 \mathrm{~m} 3$ as half height and width of Borobudur temple. Every person uses plastic bags approximately 700 pieces every year. Therefore, Indonesia produces 4.000 waste plastic bags everyday, most of them are recycled. The rest of them are left or thrown to the rivers, drainage, beaches or even to the sea. And most of them stay there for along time which is caused of flood every where. Ironically, since plastic bags are given for free of charge, people have a tendency to use these bags excessively.

Plastic bags have been drawing the attention of the government. The policy of regulation is to reduce the environmental burden of plastic bags. Indonesian government stated that using fewer plastic bags to press the quantity of plastic trash in order not to make harm environment. In this case, the Government Bandung City stated local regulation (Perda No. 17 tahun 2012) that decreasing the use of plastic bags which their basic materials are not disentangled easily could damage the quality of environment. It is also supported by Amendment from the Ministry of Environment and Forestry (Surat Edaran No. S.1230/PSLB3-PS/2016).

The customers of super markets or mini markets no longer get plastic bags for free. The government has imposed the policy that plastic bags have to be paid Rp 200 per piece, in order to reduce plastic waste since 21 February 2016. This government prescription aims to make the people care of their environment.

Alamendah (2016:01) stated that the awareness of Indonesian society in using plastic bags and managing waste plastic is still very low. Whereas, waste plastic is very dangerous to the environment condition. As, plastics themselves entry to environment, plastics resist biodegradation and pollute for decades and centuries, and pose risk to human health and environment. They travel long distances, are resistant to moisture because of their light weight, block drains during rains. Plastics contribute to large volume of solid wastes in each regency and are caused air, oceans, soil, livestock, wildlife, and marine life pollution that could be called visible pollution.

Education also plays a powerful role in increasing local involvement and contribution in ecotourism. As stated by Blamey, R.K. ( 2003: 05) that ecotourism is identified four principles of responsible tourism: minimazing environmental impacts, respecting host cultures, maximizing the benefit to 
local people, and maximizing tourist satisfaction. Straughan and Roberts (1999) found that customers with high levels of concern about the environment engage in more intense ecofriendly behaviour if they feel their efforts and action can be effective in resolving environmental problems. Although customers with high environmental concerns do not always buy green products, it may be true that they are more likely to perform ecologically favorable behaviours in their everyday lives and make eco-friendly purchasing decision.

Further, Han et al. (2009) indicated that customers' favorable attitude towards green behaviours, which has an important role in ecological decision making process, is generally derived from their judgment about their ability to affect ecological problems. The more the individuals think their effort can solve problems associated with the environment, the more likely they are to undertake environmentally conscious behaviours in their everyday lives, form positive attitudes towards ecologically conscious behaviours and make eco-friendly purchasing decisions.

\section{RESEARCH METHODOLOGY}

In this research, the writers are focusing on minimizing environmental impacts by observing, interviewing, and distributing questionaires to some respondents: ladies, housewives, and career women who usually go shopping at supermakets or minimarkets; such as Griya Setiabudi, Borma Setiabudi, Indomaret Buahbatu, and Alfamart Buahbatu in Bandung.

There are several criteria that may be used to assess the quality of methodology used in a study, stated by Weaver, D.B. (2003:600)

\section{Observation}

The writers observe the attitude of customers who go shopping to the supermarkets or minimarkets at the check out counters whether they have good awareness of having ecotourism or keeping green environment by providing their own shopping bags or they still need plastic bags provided by supermarkets or minimarkets.

2. Interview

In this research, the writers interview supervisors and shopkeepers about preferences of customers to bring their own shopping bags or get the plastic bags provided by the supermarkets or minimarkets as the data.

3. Questionnaires

The writers distribute the questionnaires to 50 respondents about using and conducting of plastic bags, also being environmentally conscious behaviour.

a. The using of plastic bags

1) Do you bring your own plastic bags when you go shopping?

2) Do you accept plastic bags provided by supermarkets or minimarkets?
3) Do you still use plastic bags when you only buy one or two items?

4) Do you try to minimize/reduce the use of plastic bags?

5) What are your reasons, anytime you don't bring your shopping bags : more practice, forget, or cheap price ?

b. The conducting of plastic bags

1) Do you keep the plastic bags after using them?

2) Do you throw the plastic bags away directly ?

3) After keeping the plastic bags, do you reuse them?

4) Do you reuse the plastic bags as the trash bags?

c. Environmentally conscious behaviour

1) Do you find plastic waste at your neighbourhood?

2) Do you realize the impact of plastic waste towards the environment?

3) Do you tidy up the environment from plastic waste?

\section{DISCUSSIONS AND ANALYSIS}

Plastic bags or polythene bags are commonly known or used as shopping bags for packaging food and other items, as stated by Ramaswany V and Sharma H.R. (2010: 01). It also happens in Indonesia especially in Bandung that all shoppers need or use plastic bags for packaging their purchases. Plastic bags are identified as LDPE ( Low Density Polyethylene) which are strong, transparent, flexible, and power protection against moisture is relatively good. LDPE could be recycled but it is difficult to be indestructible naturaly. Therefore it could cause environmental pollution.

Decreasing the use of plastic bags, the Government Bandung City makes local regulation as the materials of plastic bags are not disentangled easily could damage the quality of environment. It is also supported by Ramaswany V. And Sharma H.R. (2010 : 01) that polythene pollution is indestructible. If Indonesian society continues to use plastic bags or polythene bags the earth would become polluted on an alarming rate. As it is proved that Indonesia has produced the biggest trash in the world and was accused as the second country producing trash.

Based on the finding that could be described as followed :

1. The using of plastic bags

a. $26 \%$ or 13 respondents bring their plastic bags, $24 \%$ or 12 respondents sometimes bring their plastic bags, and the rest $50 \%$ or 25 respondents bring their own shopping bags not plastic bags. 
b. $60 \%$ or 30 respondents accept plastic bags, $16 \%$ or 8 respondents sometimes accept plastic bags, and $24 \%$ or 12 respondents do not accept plastic bags.

c. $50 \%$ or 25 respondents use plastic bags, $24 \%$ or 12 respondents sometimes use plastic bags, and the rest $26 \%$ or 13 respondents do not use plastic bags when they only buy one or two items and put them into their handbags.

d. $30 \%$ or 15 respondents try to minimize the use of plastic bags, $56 \%$ or 28 respondents sometimes reduce the use of plastic bags, and $14 \%$ or 7 respondents arenot aware yet of minimizing the use of plastic bags.

e. $28 \%$ or 14 respondents feel more practice use plastic bags provided, $6 \%$ or 3 respondents forget bring their own shopping bags, and $66 \%$ or 33 respondents feel the price of plastic bags provided is cheap.

Table 1

The Using of Plastic Bags

\begin{tabular}{|c|c|c|c|c|c|c|c|c|}
\hline \multirow[t]{2}{*}{ No. } & \multirow[t]{2}{*}{ Statements } & \multicolumn{2}{|c|}{ Yes } & \multicolumn{2}{|c|}{ Sometimes } & \multicolumn{2}{|c|}{ No } & \multirow[t]{2}{*}{ Total } \\
\hline & & $\mathrm{n}$ & $\%$ & $\mathrm{n}$ & $\%$ & $\mathrm{n}$ & $\%$ & \\
\hline 1 & $\begin{array}{l}\text { You bring } \\
\text { your own } \\
\text { plastic bags } \\
\text { when you go } \\
\text { shopping. }\end{array}$ & 13 & 26 & 12 & 24 & 25 & 50 & 88 \\
\hline 2 & $\begin{array}{l}\text { You accept } \\
\text { plastic bags } \\
\text { provided by } \\
\text { supermarket } \\
\mathrm{s} \text { or } \\
\text { minimarkets }\end{array}$ & 30 & 60 & 8 & 16 & 12 & 24 & 118 \\
\hline 3 & $\begin{array}{lr}\text { You } & \text { use } \\
\text { plastic } & \text { bags } \\
\text { when you } \\
\text { only buy } \\
\text { one or two } \\
\text { items. }\end{array}$ & 25 & 50 & 12 & 24 & 13 & 26 & 112 \\
\hline 4 & $\begin{array}{l}\text { You try to } \\
\text { minimize } \\
\text { the use of } \\
\text { plastic bags. }\end{array}$ & 15 & 30 & 28 & 56 & 7 & 14 & 108 \\
\hline & TOTAL & 249 & 41.5 & 120 & 30 & 57 & 28.5 & 426 \\
\hline
\end{tabular}

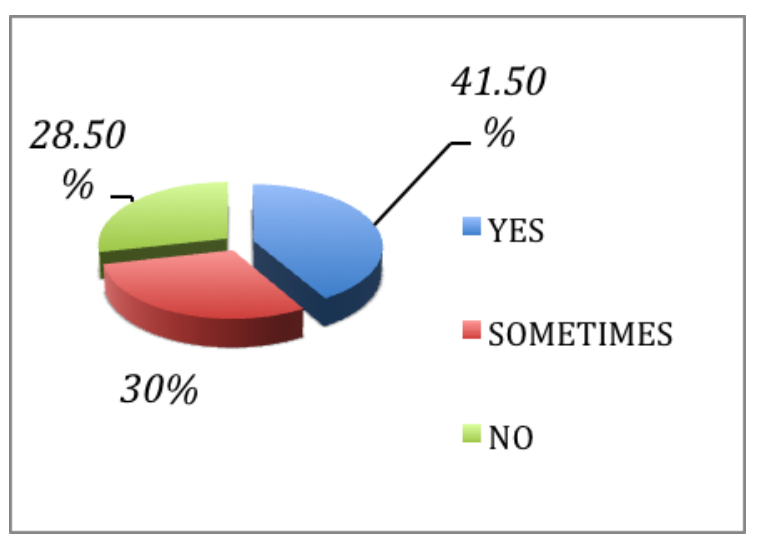

Pie chart 1

The Using of Plastic Bags

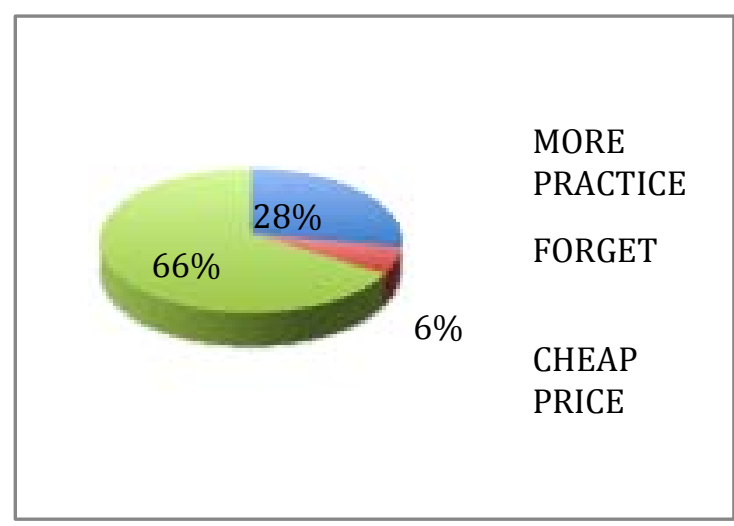

Pie chart 2

Customers'Reason Not to Bring Their Shopping Bags

2. The conducting of plastic bags

a. $72 \%$ or 36 respondents keep the plastic bags after using them, $18 \%$ or 9 respondents sometimes keep the plastic bags after using them, and $10 \%$ or 5 respondents do not keep the plastic bags after they use them.

b. $6 \%$ or 3 respondents throw the plastic bags away directly, $24 \%$ or 12 respondents sometimes throw the plastic bags away directly, and the rest $70 \%$ or 35 respondents do not throw the plastic bags away directly.

c. $80 \%$ or 40 respondents reuse the plastic bags after keeping them, $14 \%$ or 7 respondents just sometimes reuse them, and $6 \%$ or 3 respondents do not use the plastic bags anymore.

d. $88 \%$ or 44 respondents reuse the plastic bags as the trash bags, $8 \%$ or 4 respondents sometimes reuse the plastic bags as the trash bags, and $4 \%$ or 2 respondents do not use the plastic bags as the trash bags anymore.
Table 2

The conducting of plastic bags

\begin{tabular}{|c|c|c|c|c|c|c|c|c|}
\hline \multirow[t]{2}{*}{ No } & \multirow[t]{2}{*}{ Statements } & \multicolumn{2}{|c|}{ Yes } & \multicolumn{2}{|c|}{$\begin{array}{c}\text { Sometim } \\
\text { es }\end{array}$} & \multicolumn{2}{|c|}{ No } & \multirow[t]{2}{*}{ Total } \\
\hline & & $\mathrm{n}$ & $\%$ & $\mathrm{n}$ & $\%$ & $\mathrm{n}$ & $\%$ & \\
\hline 1 & $\begin{array}{l}\text { You keep the } \\
\text { plastic bags } \\
\text { after using } \\
\text { them }\end{array}$ & 36 & 72 & 9 & 18 & 5 & 10 & 131 \\
\hline 2 & $\begin{array}{l}\text { You throw } \\
\text { the plastic } \\
\text { bags away } \\
\text { directly }\end{array}$ & 3 & 6 & 12 & 24 & 35 & 70 & 68 \\
\hline
\end{tabular}




\begin{tabular}{|c|l|c|c|c|c|c|c|c|}
\hline 3 & $\begin{array}{l}\text { After keeping } \\
\text { the plastic } \\
\text { bags, you } \\
\text { reuse them }\end{array}$ & 40 & 80 & 7 & 14 & 3 & 6 & 137 \\
\hline 4 & $\begin{array}{l}\text { You reuse the } \\
\text { plastic bags } \\
\text { as the trash } \\
\text { bags }\end{array}$ & 44 & 88 & 4 & 8 & 2 & 4 & 142 \\
\hline & TOTAL & 369 & 61.5 & 64 & 16 & 45 & 22.5 & 478 \\
\hline
\end{tabular}

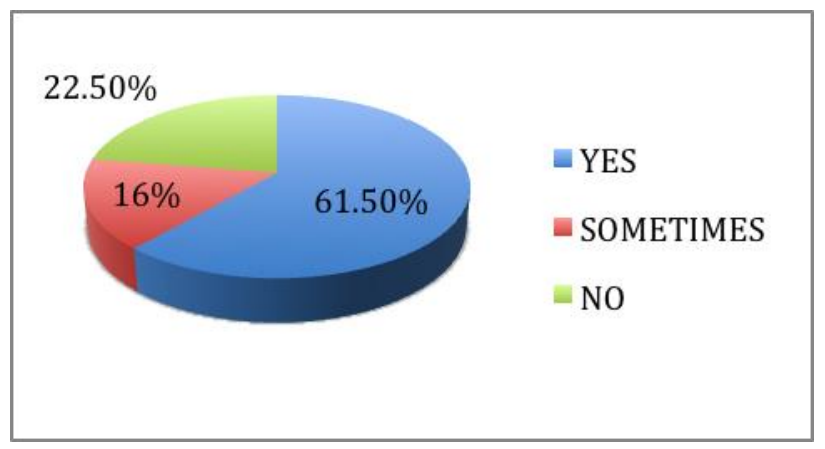

Pie chart 3

The conducting of plastic bags

3. Environmentally conscious behaviour

a. $56 \%$ or 28 respondents find plastic waste at their neighbourhood, $24 \%$ or 12 respondents sometimes find plastic waste at their neighbourhood, and the rest $20 \%$ or 10 respondents do not find plastic waste at their neighbourhood.

b. $72 \%$ or 36 respondents realize the impact of plastic waste towards the environment, $10 \%$ or 5 respondents only sometimes realize the impact of plastic waste towards the environment, and $18 \%$ or 9 respondents do not realize the impact of plastic waste towards the environment or they do not care to the green environment.

c. $24 \%$ or 12 respondents tidy up their environment from plastic waste, $70 \%$ or 35 respondents sometimes tidy up their environment from plastic waste, and just $6 \%$ or 3 respondents do not tidy up their environment from plastic waste. They just ignore plastic waste there on the ground or anywhere around their environment

Table 3

Environmentally Conscious Behaviour

\begin{tabular}{|c|l|c|c|c|c|c|c|c|}
\hline No & Statements & \multicolumn{2}{|c|}{ Yes } & \multicolumn{2}{|c|}{ Sometimes } & \multicolumn{2}{|c|}{ No } & Total \\
\cline { 3 - 8 } & $\mathrm{n}$ & $\%$ & $\mathrm{n}$ & $\%$ & $\mathrm{n}$ & $\%$ & \\
\hline 1 & $\begin{array}{l}\text { You find } \\
\text { plastic waste } \\
\text { at your } \\
\text { neighbourho } \\
\text { od }\end{array}$ & 28 & 56 & 12 & 24 & 10 & 20 & 118 \\
\hline 2 & $\begin{array}{l}\text { You realize } \\
\text { the impact of } \\
\text { plastic waste } \\
\text { towards }\end{array}$ & 36 & 72 & 5 & 10 & 9 & 18 & 127 \\
\hline
\end{tabular}

\begin{tabular}{|c|l|c|c|c|c|c|c|c|}
\hline & environment & & & & & & & \\
\hline 3 & $\begin{array}{l}\text { Tidy up the } \\
\text { environment } \\
\text { from plastic } \\
\text { waste }\end{array}$ & 12 & 24 & 35 & 70 & 3 & 6 & 109 \\
\hline & TOTAL & 228 & 50.7 & 104 & 34.6 & 22 & 14.7 & 354 \\
\hline
\end{tabular}

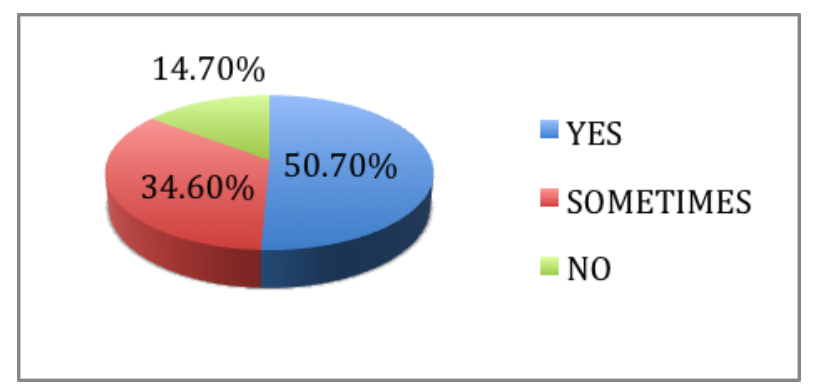

Pie chart 4

Environmentally Conscious Behaviour

\section{CONCLUSION}

Being green is away of living sustainably that has to be practiced every day. Therefore, it also means constantly thinking of every opportunity to conserve the environment and to act on those opportunities of being aware of going green. Every little change helps to support the green life style. In other words of the little ways to live green are accomplished, the larger changes will follow.

It is important to state that Be Green or Green Living, not only a statement on the $t$-shirts and bags. So everybody should be aware of being green and living environmentally friendly. It is not only reducing plastic waste but finding ways for a community to be interested in the environmental practices.

The findings that the writers get are most customers still accept plastic bags provided by supermarkets and minimarkets, even they only buy one or two items as the price of the plastic bags is very cheap. The customers also keep plastic bags and reuse them for packaging any stuff as trash bags. Most of them realize the impact of plastic waste towards the environment, but they only sometimes tidy up the plastic waste.

\section{SUGGESTIONS}

There are many ways reducing the use of plastic bags, they are: people have to be aware of the effect of plastic waste to environment and they need to realize the waste of plastic towards human health. They need to have their effort and action that can be effective in resolving environmental problems, so our next generation could enjoy fresh environment. 


\begin{tabular}{|c|l|c|c|c|c|c|c|c|}
\hline 3 & $\begin{array}{l}\text { After keeping } \\
\text { the plastic } \\
\text { bags, you } \\
\text { reuse them }\end{array}$ & 40 & 80 & 7 & 14 & 3 & 6 & 137 \\
\hline 4 & $\begin{array}{l}\text { You reuse the } \\
\text { plastic bags } \\
\text { as the trash } \\
\text { bags }\end{array}$ & 44 & 88 & 4 & 8 & 2 & 4 & 142 \\
\hline & TOTAL & 369 & 61.5 & 64 & 16 & 45 & 22.5 & 478 \\
\hline
\end{tabular}

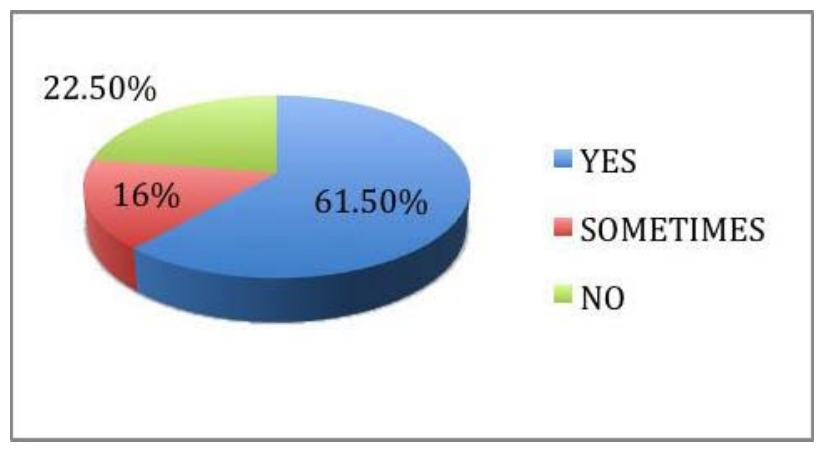

Pie chart 3

The conducting of plastic bags

3. Environmentally conscious behaviour

a. $56 \%$ or 28 respondents find plastic waste at their neighbourhood, $24 \%$ or 12 respondents sometimes find plastic waste at their neighbourhood, and the rest $20 \%$ or 10 respondents do not find plastic waste at their neighbourhood.

b. $72 \%$ or 36 respondents realize the impact of plastic waste towards the environment, $10 \%$ or 5 respondents only sometimes realize the impact of plastic waste towards the environment, and $18 \%$ or 9 respondents do not realize the impact of plastic waste towards the environment or they do not care to the green environment.

c. $24 \%$ or 12 respondents tidy up their environment from plastic waste, $70 \%$ or 35 respondents sometimes tidy up their environment from plastic waste, and just $6 \%$ or 3 respondents do not tidy up their environment from plastic waste. They just ignore plastic waste there on the ground or anywhere around their environment

Table 3

Environmentally Conscious Behaviour

\begin{tabular}{|c|l|c|c|c|c|c|c|c|}
\hline No & Statements & \multicolumn{2}{|c|}{ Yes } & \multicolumn{2}{|c|}{ Sometimes } & \multicolumn{2}{|c|}{ No } & Total \\
\cline { 2 - 8 } & $\mathrm{n}$ & $\%$ & $\mathrm{n}$ & $\%$ & $\mathrm{n}$ & $\%$ & \\
\hline 1 & $\begin{array}{l}\text { You find } \\
\text { plastic waste } \\
\text { at your } \\
\text { neighbourho } \\
\text { od }\end{array}$ & 28 & 56 & 12 & 24 & 10 & 20 & 118 \\
\hline 2 & $\begin{array}{l}\text { You realize } \\
\text { the impact of } \\
\text { plastic waste } \\
\text { towards }\end{array}$ & 36 & 72 & 5 & 10 & 9 & 18 & 127 \\
\hline
\end{tabular}

\begin{tabular}{|c|l|c|c|c|c|c|c|c|}
\hline & environment & & & & & & & \\
\hline 3 & $\begin{array}{l}\text { Tidy up the } \\
\text { environment } \\
\text { from plastic } \\
\text { waste }\end{array}$ & 12 & 24 & 35 & 70 & 3 & 6 & 109 \\
\hline & TOTAL & 228 & 50.7 & 104 & 34.6 & 22 & 14.7 & 354 \\
\hline
\end{tabular}

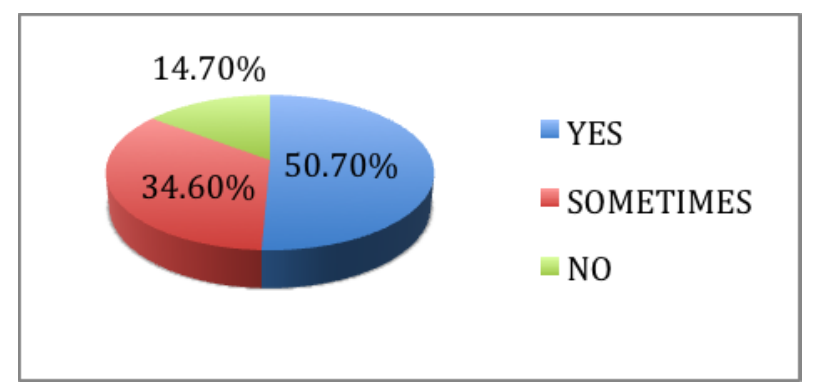

Pie chart 4

Environmentally Conscious Behaviour

\section{CONCLUSION}

Being green is away of living sustainably that has to be practiced every day. Therefore, it also means constantly thinking of every opportunity to conserve the environment and to act on those opportunities of being aware of going green. Every little change helps to support the green life style. In other words of the little ways to live green are accomplished, the larger changes will follow.

It is important to state that Be Green or Green Living, not only a statement on the $t$-shirts and bags. So everybody should be aware of being green and living environmentally friendly. It is not only reducing plastic waste but finding ways for a community to be interested in the environmental practices.

The findings that the writers get are most customers still accept plastic bags provided by supermarkets and minimarkets, even they only buy one or two items as the price of the plastic bags is very cheap. The customers also keep plastic bags and reuse them for packaging any stuff as trash bags. Most of them realize the impact of plastic waste towards the environment, but they only sometimes tidy up the plastic waste.

\section{SUGGESTIONS}

There are many ways reducing the use of plastic bags, they are: people have to be aware of the effect of plastic waste to environment and they need to realize the waste of plastic towards human health. They need to have their effort and action that can be effective in resolving environmental problems, so our next generation could enjoy fresh environment. 


\section{REFERENCES}

[1] Alamendah.2009. Dampak Plastik Terhadap Lingkungan. Alamendah's Blog.

[2] Blamey.R.K.2003. Principles of Ecotourism. Biddles Limited. United Kingdom

[3] Darsono. V. 1995. Pengantar Ilmu Lingkungan, Universitas Atmajaya. Yogjakarta

[4] Han.et.al.2009. Empirical Investigation of the Roles of Attitudes Toward Green Behaviors, overall image, gender, and age in hotel customers' ecofriendly decision-making process. International Journal of Hospitality Management, 28, 519-528.

[5] Peraturan Daerah Kota Bandung Nomor 17 tahun 2012.

[6] Rahyang, Nusantara. 2016. Buatkan Peraturan Diet Kantong Plastik. Jakarta Selatan. Indoensia.

[7] Ramaswamy V and Sharma .H.R. 2010. Plastic Bags-Threat to Environment and Cattle Health: A Retrospective Study from Gondar City of Ethiopia, Gondar. Ethiopia.

[8] Steinweg Claire. 2015. Environmental Science. IOWA State University.

[9] Straughan and Roberts. 1999. Environmental Segmentation Alternatives: A Look at Green Consumer Behavior in the New Millennium. Journal of Consumer Marketing, 16 (6). 558-575.

[10] Weaver D.B. 2003. Ecotourism in the Context of Other Tourism Types. Biddles Limited. United Kingdom.

[11] National Geographics Indonesia Kebijakan membayar kantong plastik $<$ http://nationalgeographic.co.id/berita/2016/01/keb ijakan-membayar-kantong-plastik-belanja-mulaiditerapkan-februari-2016> 